\title{
Historein
}

Vol 8 (2008)

Performing Emotions: Historical and Anthropological Sites of Affect

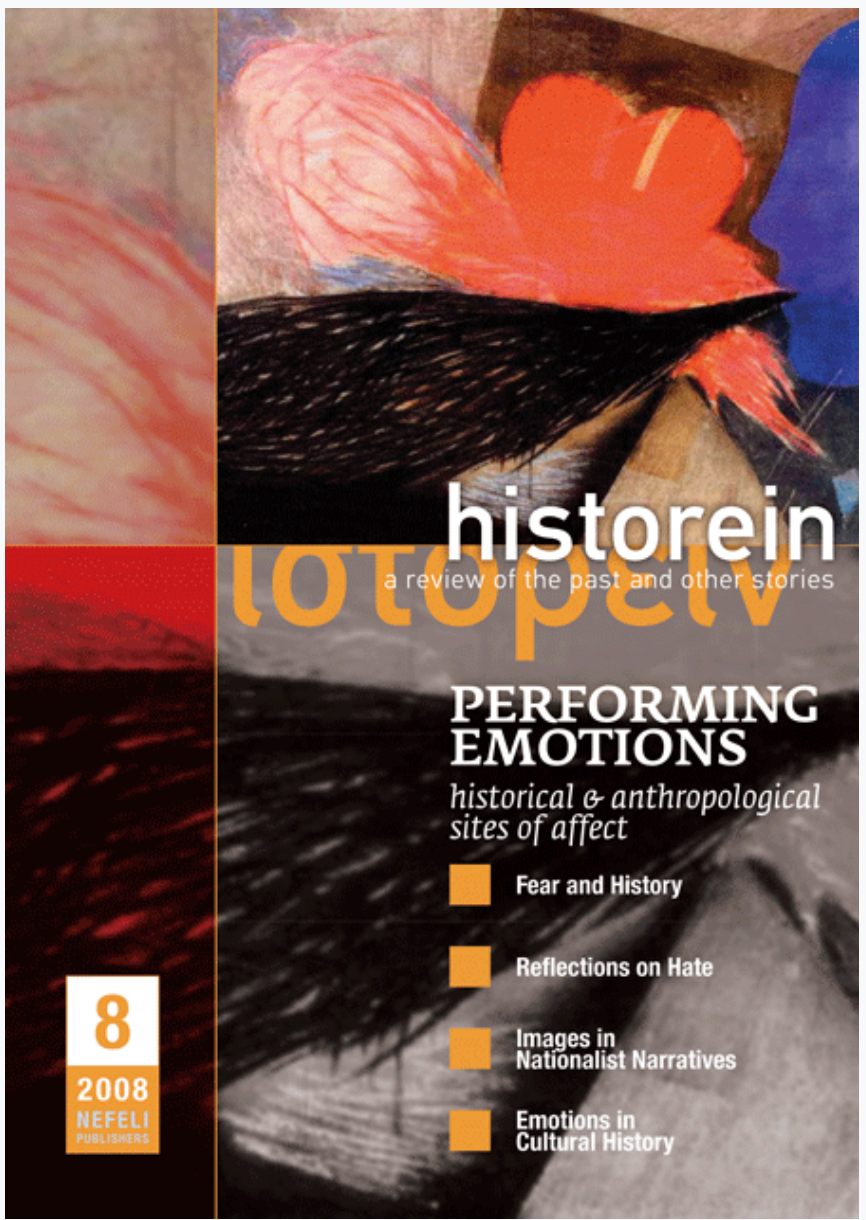

\section{Of Rats and Names (Reflections on Hate)}

Gil Anidjar

doi: $\underline{10.12681 / \text { historein.35 }}$

\section{Copyright $\odot$ 2012, Gil Anidjar}

\section{(@) $\oplus \Theta \odot$}

This work is licensed under a Creative Commons Attribution-NonCommercialShareAlike 4.0.

To cite this article:

Anidjar, G. (2009). Of Rats and Names (Reflections on Hate). Historein, 8, 29-40. https://doi.org/10.12681/historein.35 
The notion of a rat [von der Vorstellung der Ratte] is inseparably bound up with the fact that it has sharp teeth with which it gnaws and bites. But rats cannot be sharptoothed, greedy and dirty with impunity: they are cruelly persecuted and mercilessly put to death by man [sie wird von den Menschen ... grausam verfolgt und schonungslos erschlagen], as the patient had observed with horror. He had often pitied the poor creatures. But he himself had been just such a nasty, dirty little wretch, who was apt to bite people when he was in a rage, and had been fearfully punished for doing so. He could truly be said to find "a living likeness of himself" [sein ganz 'natürlich Ebenbild' (sic)] in the rat. —Sigmund Freud'

\section{1}

This much could have been obvious: Rat Man was a Jew and Freud's case study on him, his "Notes upon a Case of Obsessional Neurosis", could tell us much about antiSemitism. ${ }^{2}$ To be sure, Jews remain unnamed in the text on the case such as it was published in its final form, and it is unclear whether the association, made famous and infamous by the Nazis, had already been established, which irrevocably linked Jews with rats in the anti-Semitic imaginary. Still, Freud's text has everything to do with Jews (fathers, rats and money, all of which were or became deeply entangled within a web of Jewish and anti-Semitic significance, which is to say that, as Freud puts it, "rats had acquired a series of symbolic meanings, to which, during the period which fol-

\section{Of Rats and Names (Reflections}

\author{
on Hate)
}

\section{Gil Anidjar}

Columbia University 
lowed, fresh ones were continually being added"). ${ }^{3}$ And it has everything to do with the response one offers to the word or to the name that is called. On the thither side of interpellation, another way to learn about Rat Man's predicament in its connection to Jewishness and anti-Semitism is by considering that the case constitutes, in fact, a grand rehearsal of Totem and Taboo (the tribe of "great criminals", the ghost of the dead father, the significance of the law and of ritual, indeed, of obsessional practice) and of Moses and Monotheism ("the great man", the power of the name, revenge and guilt). Minimally, Rat Man's case was about religion all along, about commands and prohibitions, superstitions, prayers, and fathers, dead or alive. It is also about prophetic dreams and belief in telepathy, hyperbolic trust in the power of thought as well as in that of the name, fear - and hope - of punishment (in this world and for all eternity), the obsession of protection and apotropaic (protective) measures, miraculous apparitions, strange Eastern practices, and life after death, which is another way to say: survivor's guilt. A deeply religious figure and the very image of heedful devotion and ascetic prohibition, Rat Man was a doctor of law (juris doctor). He was obsessed with revenge and, not surprisingly therefore, he was fond of biblical stories. Rat Man declared his religion - a difficult and personal blend of motives and actions in which belief and practice, while not necessarily connected, proliferate ("thus he was able to have two different creeds and two different outlooks upon life"). ${ }^{4}$ He had confessed it to Freud upon the very first (or was it the second?) meeting.

The only other piece of information that I obtained from him during this [first] hour was that from the very first, on all the previous occasions on which he had had a fear that something would happen to people he loved no less than on the present one, he had referred the punishments not only to our present life but also to eternity - to the next world [in die Ewigkeit]. Up to his fourteenth or fifteenth year he had been devoutly religious [er war ... sehr gewissenhaft religiös gewesen], but from that time on he had gradually developed into the free-thinker that he was today. He reconciled the contradiction between his beliefs and his obsessions by saying to himself, "What do you know about the next world? [was weißt du vom Leben im Jenseits?] Nothing can be known about it. You're not risking anything - so do it!" This form of argument seemed unobjectionable to a man who was in other respects particularly clear-headed, and in this way he exploited the uncertainty of reason in the face of these questions to the benefit of the religious attitude [fromme Weltanschauung] which he had outgrown. (15/G394)

Today, Rat Man teaches us perhaps most about hate and its staying power. Therefore, it teaches us about the hatred of the Jews - anti-Semitism - and its current, hyperbolic policing. This may not come to full clarification in what follows, but it is hardly as obscure as it may seem, for the case readily introduces us to the question of words that wound and their failure, that is to say, then and finally, to the question of interpellation. What does it mean to be interpellated? What does it mean to be interpellated, among others, by anti-Semitism? What does it mean to consider oneself the addressee of hate speech and of murderous acts? Much as Althusser will later demonstrate, Freud already testifies to that which links the question of interpellation - and by extension, injurious speech, acts and actes manqués - to the police. The word interpeller, in 
French, has the technical, legal and juridical, meaning of "hailing, arresting, seizing" used by the courts and by the police. Interpellation, here, also recalls insult and murder and murderous injury. It produces or evokes subjection and identification. Strong affects are at stake, and so are mistaken associations, inevitably, as well as mistaken identifications. "We are not used to feeling strong affects", Freud explains as if that explained something, or anything really. "We are not used to feeling strong affects without their having any ideational content, and therefore, if the content is missing, we seize as a substitute [und nehmen ... als Surrogat auf] upon another content which is in some way suitable, much as our police, when they cannot catch the right murderer, arrest a wrong one instead [einen unrechten an seiner Stelle verhaftet]. ${ }^{.5}$ Such failures may well constitute successes, Freud later makes clear, and some interpellers easily become interlopers, who redirect everything their way, thus producing and fashioning their own devoted or persecuting subjects. Like the proverbial customer, such callers may always be right. "So too the king cannot be mistaken; if he addresses one of his subjects by a title which is not his [wenn sie einen Untertan mit einem ihn nicht gebührenden Titel angesprochen hat], the subject bears that title ever afterwards." (56/G437) Rat Man - le bien (ou mal) nommé - is a story of interpellation. It is the story of hate and of its policing.

Were it possible, when speaking about Freud, the scene around which this reading will gravitate could be described as unforgettable. And indeed, who could forget the child? Who - granted even the slightest familiarity with Freud's corpus - could fail to recall the child who, still being beaten, struck back at his father by hitting him with the gift of prophecy? Surprisingly or not, the latter responds to kin in kind, or at least with a blessing and a curse. " "The child will be either a great man or a great criminal!" Undoubtedly among the better known citations within the Freudian text, and much like the phrase "the talking cure" had earlier, this sentence (for it is a sentence, perhaps even a death sentence), which Freud himself never uttered but that he reported and wrote, came in a way to name or describe psychoanalysis. Naming the great man and the great criminal, hailing and calling them, as it were, the sentence resonates across the fields and disciplines which Freud affected and changed. An instance of that which binds and unbinds father to son - male sociability, in a nutshell - the memory of which is sustained by the mother, the sentence and the scene which it ties and punctuates essentially stages the social according to Freud, from art, religion and politics ("a great man") to normality and perversion, law and the police ("a great criminal"). The entirety of the "Notes upon a Case of Obsessional Neurosis" is thus dominated by hate, the hate of a child for his father, and that of a father for his ancestors." As the event of a collective psychology, the case is structured and governed by self-hate. But more importantly, the case is sustained by hate as it is itself carried by speech, words of hate and hate speech, abuse, insults and curses, incantations that end or change, that turn around, as it were, at the turning point of the case of the Rat Man. ("Things soon reached a point at which, in his dreams, his waking phantasies, and his associations, he began heaping the grossest and filthiest abuse upon me and my family [aufs gröblichtste und unflätigste beschimpfte], though in his deliberate actions he never treated me with anything but the greatest respect. His demeanour as he repeated these insults [dieser Beschimpfungen] to me was that of a man in despair" 
(48/G429)). With the greatest measure of respect, then, insults, curses and abusive words proliferate throughout the text. But the case is also a narrative, a tale of hate, the story of a murder or murders, the repetition, many have remarked, of the legend of Prince Hamlet who, interpellated, witnesses his father's ghostly returns ("And although he had never forgotten that his father was dead, the prospect of seeing a ghostly apparition of this kind had no terrors for him"), ${ }^{8}$ and seeks to avenge his father's murder - but we know, of course, who does the murdering of fathers ("Thoughts about my father's death, occupied my mind from a very early age and for a long period of time"). ${ }^{9}$ Rat Man is the case of an individual who, interpellated, places himself before the law, and "spontaneously converts a given statement into a command" thereby endowed with force of law. ${ }^{10}$ It is a tale of interpellation - Fate [Das Schicksal] had called: "she had called out a 'complex stimulus word' [ein Komplexreizwort zugerufen]" and he had reacted to it."11 It is the story of a call among others which, Avital Ronell has shown, inscribes itself and runs through multiple channels and traditions, and media, from Abraham to Moses and, closer to us, from Heidegger and Levinas to Althusser and Derrida, Butler and Ronell herself. The call, perhaps an insult, never reaches its destination. Minimally, it procrastinates, but more often than not, something happens, running interferences, something or someone inserts itself (rats, nots, impertinent laughter or dead fathers, Freud himself, or an evil spirit, God even) and disrupts the call, whether it is a prayer call, or a call of prophecy (as if Balaam was not just like every other prophet, as if every prophet was not always already inverted, inserted), a blessing or a curse. The call, then, misses its intent. Or addressee.

At the time of the revival of his piety he used to make up prayers for himself, which took up more and more time and eventually lasted for an hour and a half. The reason for this was that he found, like an inverted Balaam [ein ungekehrter Bileam], that something always inserted itself into his pious phrases [in die frommen Formeln immer etwas einmengte] and turned them into their opposite. For instance, if he said, "May God protect him", an evil spirit would hurriedly insinuate a "not". On one such occasion the idea occurred to him of cursing instead, for in that case, he thought, the contrary words would be sure to creep in. (35/G415)

The call addresses no one, no one in particular, yet it chooses and elects one - the chosen one for the better and for the worse, and it apparently forces one, not just anyone but that one, to turn and respond, "Here I am!" To be more precise, and contrary to received opinion, it is not just the One who answers so. It is rather that "the interpellation of individuals as subjects presupposes the 'existence' of a Unique and central Other subject".12 Thus, through the failures of a monotheism that is nothing less than biblical, there is always more than one chosen people. Indeed, "one individual (nine times out of ten it is the right one) turns round, believing/suspecting/knowing that it is for him, i.e., recognising that 'it really is he' who is meant by the hailing."13 Every one among nine, nine out of ten, almost a minyian, a quorum which may be left hanging, like a jury without a prayer, if some one, when some one, the other one, interrupts or fails to respond. Can one fail to respond? Could any interruption, even a non-interruption, fail to qualify as a response? The calls have been made, the blessing or the curse issued, the insult hurled, and the response that I am, therefore, follows. Witness, then, the force of interpellation, transmitted, says Freud and what else did you expect? the Spanish Inquisition? Yes, well, we are talking about the Jews, and therefore about anti-Semitism - by way of the mother. 
To my great astonishment the patient then informed me that his mother ${ }^{14}$ had repeatedly described to him an occurrence ... which dated from his earliest childhood and had evidently escaped being forgotten by her on account of its remarkable consequences. He himself, however, had no recollection of it whatever. The tale was as follows. When he was very small - it became possible to establish the date more exactly owing to its having coincided with the fatal illness of an elder sister - he had done something naughty, for which his father had given him a beating. The little boy had flown into a terrible rage and had hurled abuse at his father even while he was under his blows [Da sei der kleine Knirps in eine schreckliche Wut geraten und habe noch unter den Schlägen den Vater beschimpft]. But as he knew no bad language [keine Schimpfwörter], he had called him all the names of common objects that he could think of, and had screamed, "You lamp! You towel! You plate!" and so on. His father, shaken by such an outburst of elemental fury, had stopped beating him, and had declared, "The child will be either a great man or a great criminal!" The patient believed that the scene made a great impression upon himself as well as upon his father. His father, he said, never beat him again; and he also attributed to this experience a part of the change which came over his own character. From that time forward he was a coward - out of fear of the violence of his own rage. His whole life long, moreover, he was terribly afraid of blows, and used to creep away and hide, filled with terror and indignation, when one of his brothers or sisters was beaten. (46/G426).

What does it mean to be the addressee of a massive death sentence? What does it mean to consider oneself the addressee of such a death sentence, even long after it has been issued and, luckily, revoked or abolished? In Jean-François Lyotard's rendering, the utterance, by a Nazi, of the word "Jew" could mean only one thing: "you are dead", or, lacking the basic structure of address, the acknowledgment of the addressee's prior existence, "Jew!" meant immediate death. Lacking address, the utterance does not permit a response. ${ }^{15}$ This impossibility of response is tied to a peculiar structure: the absence or failure of address in an utterance (the absence of a "you" who could thereby respond) is defined by the success of its reach. The utterance reaches its proper addressee: the dead. No response is possible because there is neither time ("Jew!" is not a threat that would open the possibility of deferral, not one that would grant the possibility of time) nor a "who" or a "you", that is addressed. There is no time and no one to respond. Beyond the possibility or impossibility of its utterance, then, the "Jew!" of the Nazi provides the ultimate example of the anti-Semitic utterance. But the question nonetheless lingers: who is the addressee of anti-Semitism? Where to locate the possibility of a mistake or failure? And who could possibly claim to be the addressee, always already to have been that which the call names and unnames? The death toll of Nazi anti-Semitism is not to be doubted. But who is it that it reached? Who, in other words, responds to anti-Semitism? Rat Man raises the possibility that the injurious calls of anti-Semitism are governed by symptoms of "mistaken identity". The "recognition", the identification of Jews with incidents that are meant or said to target Jews, incidents said to be anti-Semitic even when they are fabricated lies or simply mistaken, is based 
on the logic of interpellation such as Rat Man exemplifies it, and which includes distinct modes of failures. "The scientific results of psycho-analysis," Freud had pertinently and presciently written, "are at present only a by-product of its therapeutic aims, and for that reason it is often just in those cases where treatment fails that most discoveries are made."16

Rat Man is about anti-Semitism because it is about interpellation, the call that names and arrests, that identifies and wounds, a call that, strictly speaking, never reaches its destination but nonetheless operates and wounds. ${ }^{17}$ Interpellation, for Rat Man, was a familiar procedure, but it also carried the risk of spectacular failure. In fact, the story of his father's death (or, as Freud more rigorously calls it, "the story of his father's illness [die Krankengeschichte seines Vaters])", is precisely such a story, a spectacular tale of call and response in a time of crisis, the flaring up of danger and the estimation of its passing (what does it mean for danger to pass?). It is about the failure to answer to one's name, to answer to the name called (Paul, that famous letter writer, is the substitute or surrogate name Freud here inserts), to respond to that which calls. In this case, it was the sick father calling, and Rat Man ("Father, can't you see l'm resting?") had gone to sleep.

One evening, thinking that the condition was one which would come to a crisis, he had asked the doctor when the danger could be regarded as over [wann die Gefahr als beseitigt gelten könnte]. "The evening of the day after tomorrow," had been the reply. It had never entered his head that his father might not survive that limit. At half-past eleven at night he had lain down for an hour's rest. He had woken up at one o'clock, and had been told by a medical friend that his father had died. He had reproached himself [Er machte sich den Vorwurf] with not having been present at his death; and the reproach had been intensified when the nurse told him that his father had spoken his name once during the last days [der Vater habe in den letzten Tagen einmal seinen Namen genannt], and said to her as she came to bed, "Is that Paul?" $(19 / G 398)^{18}$

Interpellation, then, and the failure of interpellation was therefore a procedure quite familiar to Rat Man. Later, instructed that he would have to pay back postal charges (a packet had been picked up and handed to him. Freud does not says for whom the packet was at this point), Rat Man engages the procedure and puts it to work at that very instant. "At that instant ... a 'sanction' had taken shape in his mind, namely, that he was not to pay back the money or it would happen - (that is, the phantasy about the rats would come true as regards his father and the lady). And immediately, in accordance with a type of procedure with which he was familiar, to combat this sanction there had arisen a command in the shape of a vow: "You must pay back the 3.80 kronen to Lieutenant A.' He had said these words to himself almost half aloud" (14). Recasting interpellation as command, hearing in any utterance the force of a law, ${ }^{19}$ Rat Man was as familiar with such calls of duty as he was with accusing reception in the form of mistaken identities. "He repeatedly addressed me as 'Captain'," writes Freud. 
The habit of interpellating was well established in the Lanzer household as well. Recalling the episode I quoted earlier and that still awaits our reading, Patrick Mahony meticulously calls attention to the chain of associations linking the names operating through Rat Man's narrative, the practice of interpellation, and the multiplication of mistaken identities that occupy us here. Freud's complete notes, along with the editor's explanation do account for a number of things. They tell us, first of all, that Lieutenant A.'s real name was David. In Freud's notes, therefore, the command is "You must give the 3.80 kronen to First Lieutenant David [Du mußt dem Obltt. [Oberleutnant] David die $3 \mathrm{Kr} 80$ zurückgeben]."20 Incidentally, David is the name that Freud mistakenly attributes to Rat Man's father, noting and correcting, one month into the analysis, that "His father was not called David, but Heinrich [sein Vater hieß nicht David, sondern Heinrich]."21 In the process of narrating his crucial story, Rat Man follows the names as well and interrupts himself by beginning to complain about his previous physicians, those who had failed to understand him. He had called, if you will, and they had neglected to respond. Rat Man singles out one famous Viennese doctor who, on call at the time, nonetheless went on later to receive the Nobel Prize. The name of this doctor was Julius Wagner von Jauregg, but Freud (and apparently Rat Man as well) refers to him simply as Wagner. Elza Hawelka, who edited Freud's manuscript for publication, surmises that there is no interruption here but only a further association. The name David, she says, must have brought to mind the character of the first theatrical performance Rat Man had ever attended as a child, a comic opera by Richard Wagner, Die Meistersinger von Nürnberg. David, then, turns out to be the name of a character - an apprentice shoe repairman, as well as a music student who knows, Hawelka writes, all the musical "commands".22 The same David (or was it another?) is constantly called, interpellated. $\mathrm{He}$ is the agent or subject of a frequent mistake in responding (he responds, for example, when reference is made, in a conversation that does not include him, to the David of Albrecht Dürer). He responds to his name as well as to that which functions, as it were, as the name of interpellation. Never sure when he is called, whether it is he who is being called, David is the name by which others are called and elected (one character becomes the object of another's love because he is said to resemble David, that is, Dürer's painting. It is at this point that David, the other one, also thinks that he is being called), unsure whether it is their turn, this time, to be called.

\begin{tabular}{|c|c|}
\hline Magdalene & David? Ah! David here? \\
\hline Eva & What shall I say? You tell me \\
\hline$(\ldots)$ & \\
\hline Magdalene & Ah, David! David! \\
\hline David & Here I am! Who's calling?23 \\
\hline
\end{tabular}

David, then, is repeatedly the name of the called (Wagner, the other one, not the good doctor, may have ironically considered that David, King David, that is, was said to be the ancestor of the Messiah, who keeps being called and never comes, although another, somehow more popular version of that story has him arrive only to be persecuted and ridiculed, crucified and abandoned). During the representation, Freud explains, Rat Man had heard "David, David!" Subsequently, "he had used the David motif as a call in the family [Das Davidmotiv hat er als Ruf in der Familie verwendet]". ${ }^{24}$ Who did Rat Man think he was? 
Judith Butler has explained that, in and through interpellation, "there is always the risk of a certain misrecognition... The one who is hailed may fail to hear, misread the call, turn the other way, answer to another name, insist on not being addressed in that way." ${ }^{25}$ Butler pursues:

Consider the force of this dynamic interpellation and misrecognition when the name is not a proper name but a social category, and hence a signifier capable of being interpreted in a number of divergent and conflictual ways. To be hailed as a "woman" or "Jew" or "queer" or "Black" or "Chicana" may be heard or interpreted as an affirmation or an insult depending on the context in which the hailing occurs (where context is the effective historicity and spatiality of the sign). If that name is called, there is more often than not some hesitation about whether or how to respond, for what is at stake is whether the temporary totalisation performed by the name is politically enabling or paralysing, whether the foreclosure, indeed the violence, of the totalising reduction of identity performed by that particular hailing is politically strategic or regressive or, if paralysing and regressive, also enabling in some way. ${ }^{26}$

Rat Man confronts us with the very elements that Butler raises here, with the figuration of a scene in which all possibilities of responses are at once entertained and dismissed, or at least rendered plausible, while the immediacy of responses, their inevitability, appears unquestionable. The effects in the scene and of the scene are granted spectacular immediacy, made all the more vivid by the complex sense of memory and forgetting within which they are inscribed. All involved are interpellated, hailed and arrested by the scene in its occurrence (the historical accuracy of which Freud does put into question in an elaborate footnote) and its aftermaths. The scene is traversed by numerous instances of interpellation. It is, as a whole, constituted as an interpellation. Consider the chain of its effects as they are reported in Freud's own narration. Freud himself begins by confessing his "great astonishment [meinem großen Erstaunen]". Rat Man's mother remembers the scene "on account of its remarkable consequences [weil sich so merkwürdige Dinge an ihn knüpften]". The father is "shaken [erschüttert] by such an outburst". And Rat Man himself believes that the scene had left an enduring impression (Eindruck) - although paradoxically not one he actually remembered. No less impressive are the results on the father's behaviour and on Rat Man's personality. Rat Man becomes "a coward" (although one wonders whether this particular "description" should not be read as the efficacious proliferation of insults, abuse and self-reproach). ${ }^{27}$ His father proceeds to stop beating him for good (for ill as well, for all I know, but at any rate, for ever). There is no question, therefore, of the "success" of the multiple interpellations operating in and around the scene in which the child hurls insults at his father, where he himself is beaten and becomes the third-person object of a prediction that is at once blessing and curse, and on the mutual transformation undergone by each of the persons present at the scene, at the time. If success is defined by efficacy, Rat Man's childhood provides us with an exemplary illustration of interpellation as the fashioning of collective psychology and sociability. 
A child, then, is being beaten. He responds to the violence inflicted upon his body by calling out insults. The father responds by calling upon him, in prophetic fashion, the chance or danger of an uncertain future. Their responses to the event are unsettling since they both assume the posture of recipient of the same violence, namely, the violence of the child's rage. "Out of the fear of the violence of his own rage" Rat Man becomes a coward (or understands himself so), and his father stops beating him, stunned by the power the child demonstrates and which promises (or threatens) of great things to come (Nietzsche, incidentally, had made similar predictions about himself). As Freud somehow gleefully points out, the father was wrong on both counts, and the son became instead a great neurotic, neither a great man nor a great criminal. But what is most extraordinary about the scene is that it reveals - or rather, it inserts itself in the space of - the absolute discrepancy between the word hurled as insult and its reception. For at no point did the father ever consider "identifying" with lamps, towels or plates. Never was the question of recognition or misrecognition at issue in the exchange, in the interpellation of the father by the son. We knew this since Derrida explained it, of course. The mark can only function by being torn from its context. In that way, it never reaches its destination. No insult could ever be received in the way it was 'sent'. No insult could ever mean the 'same' for sender and for addressee. This would further mean that neither recognition nor misrecognition is possible (both are equally impossible) in the case of interpellation, indeed, in any case. Clearly, the father is affected. What he receives is the rage of the child, thus alerting us to the difference between hate speech and the speaking of hate (Rat Man speaks his hate, yet what he utters is anything but hate speech). But as Imre Kertész reminds us, pain and injury, even to the point of death, do not determine meaning. Had the father died right at that moment, he would not have died a lamp or a towel. The insult or the curse - interpellation - may therefore well be a death sentence, but it fails a priori to function, indeed, to operate as an identification. It is from this originary failure, out of the impossibility of naming the other without the response of the other - that interpellation comes to function as a figure of subjection and of identification. Interpellation hails. But so what? Anti-Semitism hails. Who would want to answer? Who is it that must answer and thereby engage in "the continued digging of the grave that others had begun to dig" and which "they did not have time to finish"? 28 This is the question that Rat Man puts to us. It is the sound of Rat Man calling. Out of rage.

\section{NOTES}

1 Sigmund Freud, "Notes upon a Case of Obsessional Neurosis", transl. Alix and James Strachey, in S. Freud, The Standard Edition of the Complete Psychological Works, London: Hogarth Press, 1955, vol. X, pp. 188-89 (for the first quote) and pp. 215-16/G435 (for the second); henceforth abbreviated as Freud, Rat Man. I quote the German original from Gesammelte Werke. Bd. VII: Werke aus den Jahren 19061909, Frankfurt am Main: Fischer Taschenbuch Verlag, 1999.

2 On Rat Man's Jewishness, the rising Jewish population of Vienna between the nineteenth and early twentieth centuries, the climate of anti-Semitism within which both Rat Man and Freud found them- 
selves at the time, and the identifications at work between analyst and analysant, transference and counter-transference, see Patrick J. Mahony, Freud and the Rat Man, New Haven: Yale UP, 1986. Pointing out some of the Yiddish expressions used during the analysis but cleaned up by Freud in the final version of the case study, Mahony refers his readers to the complete notes made by Freud during the treatment rather than to the heavily edited "original record of the case" published in the Standard Edition. Instead, Mahony consulted the manuscript directly as well as the bilingual (German and French) critical edition published by Elza Ribeiro Hawelka (Freud, L'homme aux rats. Journal d'une analyse, ed. E. R. Hawelka, Paris: Presses Universitaires de France, 1974), henceforth abbreviated as Freud, Journal). In what follows, I will refer to Freud's patient, Ernst Lanzer, as Rat Man. Incidentally, Mahony also discovered that Rat Man's Jewish middle name was the same as that of Freud's own father, Jakob. Whether Freud knew this or not is unclear. Throughout his study, Mahony also underscores the link between obsessional neurosis and religion in Freud's work.

3 Freud, Rat Man, p. 213. As much as I hate to grant them any originality (and assuming that it matters at all), the Nazis may have been the first consistently to compare Jews to rats, which would begin to explain the lack of explicit references in Rat Man and in discussions thereof. As textual identifications of rats with money ("Jeder Gulden - eine Ratte"), and of rats with syphilis (a well-known "Jewish" disease) demonstrate, the association is nonetheless transitively operative in Freud's text ("So treffen in Ratten, Geld und Syphilis zusammen", Freud, Journal, pp. 166-68). Rat Man retrospectively attributes syphilis to his father and tells numerous stories about rats. And cats too, one of whom is even made gruesomely "kosher" (Freud, Journal, p. 174).

4 Freud, Rat Man, p. 248.

5 Freud, Rat Man, p. 176/G400.

6 Immanuel Kant had already associated the Jews, "those Palestinians living among us", with that particular undecidability, locating them in the space between blessing and curse (for a discussion of that passage in Kant's Anthropology see Avital Ronell, Stupidity, Urbana: University of Illinois Press, 2002, esp. pp. 302-3).

7 As Freud reports, Rat Man's father never wanted to be baptised himself, "but he much regretted that his ancestors did not spare him this unpleasant affair [aber sehr bedauert daß seine Ahnen ihm nicht dieß unangenehme Geschäft abgenommen]" (Freud, Journal, p. 204). As to his son, Heinrich Lanzer often said that he would not oppose his conversion to Christianity. One can only wonder about Heinrich's sentiments vis-à-vis his in-laws, the Saborskys, who were themselves observant Jews. It is during the same session of 27 December 1907, and in the process of detailing this religious matter, that Rat Man recalls expecting the return of his father's ghost at night, working and masturbating, devoted and defiant, wishing him ill and well. Heinrich is later, and somehow obscurely, said to have put "the Jews" to work to clear up the snow blocking the arrival of the trains. The Jews - but why the Jews? - were exceptionally allowed entry on the marketplace in order to work, a place from which they were usually barred (p. 212). The episode leads to an unpleasant exchange with an officer whose gesture of gratitude and recognition for a job well done appears to the father as highly hypocritical. Circuits of anti-Semitism are here difficult to ignore.

8 Sigmund Freud, Rat Man, pp. 174-75. And later: "This crazy conduct becomes intelligible if we suppose that he was acting as though he expected a visit from his father at the hour when ghosts are abroad. He had on the whole been idle at his work during his father's lifetime, and this had often been the cause 
of annoyance to his father. And now that he was returning as a ghost, he was to be delighted at finding his son hard at work. But it was impossible that his father should be delighted at the other part of his behaviour; in this therefore he must be defying him" (p. 204). A final discussion of the father's ghost occurs on p. 222. Freud mentions and quotes Shakespeare on p. 180 (Julius Caesar) and quotes Hamlet in particular towards the end of the case history (p. 241, n. 2). Avital Ronell attributes to Patrick Lacoste the pointing out of the "father complexes shared by both heroes", namely, Hamlet and Rat Man. Ronell underscores the concern with rats that they also share ("Hamlet, when he kills Polonius, rather convulsively screams 'a rat, a rat'") and points to "the famous acknowledgment of the doctor in Vienna to whom Hamlet futurally appeals" (Avital Ronell, "The Sujet Suppositaire: Freud, And/Or, the Obsessional Neurotic Style (Maybe)", in Finitude's Score: Essays for the End of the Millennium, Lincoln: University of Nebraska Press, 1994, p. 116).

9 Freud, Rat Man, p. 162. And later: "And thereupon the idea had come to him that she [namely, the little girl the patient had been in love with at the time] would be kind to him if some misfortune were to befall him; and as an instance of such a misfortune his father's death had forced itself upon his mind. He had at once rejected the idea with energy. And even now he could not admit the possibility that what had arisen in this way could have been a 'wish'" (p. 178). Finally, "Several years after his father's death, the first time he experienced the pleasurable sensations of copulation, an idea sprang into his mind: 'This is glorious! One might murder one's father for this!'” (p. 201).

10 Ronell, "The Sujet Suppositaire", p. 113. Freud speaks of Rat Man's "literal obedience", even of his "convulsive obedience" (Freud, Rat Man, p. 218).

11 Freud, Rat Man, p. 216/G435.

12 Louis Althusser, "Ideology and Ideological State Apparatuses”, transl. Ben Brewster, in Lenin and Philosophy and Other Essays, New York: Monthly Review Press, 1971, p. 178.

13 Ibid., pp. 174-75.

14 In the original notes, Rat Man had said that the scene, which he could not remember, had been repeatedly reported to him by his father ("die man ihm sehr oft berichtet hat, der Vater selbst"), not by his mother (Freud, Journal, p. 106). In the lines that follow the description I here quote, Freud writes that "the patient subsequently questioned his mother again. She confirmed the story", adding a few details (Freud, Rat Man, p. 206).

15 Jean-François Lyotard, Le différend, Paris: Minuit, 1982.

16 Freud, Rat Man, p. 208n.

17 Focusing on postal figures and offices, Ronell engages the problems of address in the case of Rat Man, pointing out that it neatly "inserts itself into the idiom of the Derridean text (The Post Card) concerned with the technology of the courier" (p. 117; and see also pp. 119ff.). Mahony and others have remarked that Freud may have conducted himself unprofessionally with Rat Man when he sent him, on one occasion, a postcard.

18 "Paul" is Freud's substitute for Rat Man's name, namely, Ernst. According to the nurse's awkward report, the father had asked "Sind Sie der Ernst?" (Freud, Journal, p. 64).

19 As Ronell puts it, "plain assertions of the sheerly constative sort, when deposited into Rat Man, spontaneously acquire the authority of commands" (p. 121). 
20 Freud, Journal, p. 46.

21 Ibid., p. 136.

22 bid., Journal, p. 177, n. 360.

23 Richard Wagner, Die Meistersinger von Nürnberg, act I, scene 1.

24 Freud, Journal, p. 176.

25 Judith Butler, The Psychic Life of Power: Theories in Subjection, Stanford: Stanford UP, 1997, p. 95; on the issue of insults and hate speech as interpellation, Butler pursues her reflections in Excitable Speech: $A$ Politics of the Performative, New York and London: Routledge, 1997, esp. in her introduction: "On Linguistic Vulnerability".

26 Butler, The Psychic Life, p. 96.

27 On the productive and proliferating dimension of interpellative and other powers, see ibid., pp. 58ff.

28 Imre Kertész, Kaddish for an Unborn Child, transl. Tim Wilkinson, New York: Vintage, 2004, p. 30. 